\title{
Fighting the Colonial Shadow in the Postcolonial Marathi Theatre: A Redefinition of Culture, Tradition and Myths of India from 1843-Present
}

\author{
Sayan Dey \\ (Department of English, Banaras Hindu University, India)
}

\begin{abstract}
The impact of the massive world wars led to universal fragmentation. The existing socio-cultural believes and practices were subjected to strict scrutiny. The massive economic losses incurred by the European countries proved to be a blessing for the colonized nations across the continents. After 1945, most of the nations across Africa and Asia gained independence. Theory already merging with the practical life of the individuals attained a new shape with the emergence of 'Postcolonial Theory.' Initially regarded as a powerful, celebratory concept, it is imprinted with several potholes. The sudden withdrawal of the colonial powers, created voids, which the nations are still struggling to fill up. The newly found independence created multiple conflicts and confusions in various fields including art and literature. This paper intends to highlight the impact of postcolonial conflicts on Marathi theatre and its struggle against the colonial shadow.
\end{abstract}

Key Words: universal fragmentation, postcolonial theory, potholes, colonial powers, Marathi theatre, colonial shadow

\section{Introduction}

Since the origin and development of English literature, criticism has always played a crucial role in defining and redefining various literary creations from multifarious perspectives. With the approaching modernity, the intellect and the outlook towards life underwent massive change. The Renaissance in the fourteenth century and the Industrial Revolution in the eighteenth century led to an outburst in the fields of science and technology. Ancient Puritan and Victorian orthodoxies were severely questioned and rejected. English literature also began experiencing major changes both in terms of creation and analysis. The trend of literary criticism slowly gave way to the development of theories. Since 1850s, a handsome number of philosophers, socialists, psychologists, politicians and literary thinkers started developing their own theories, related to the common, individual life experiences. Theories like Structuralism, Post-structuralism, Deconstruction, Marxism, Formalism, Existentialism, Absurd Theatre, Feminism, etc. enriched the intellect of the common man in several ways. Individuals probed into the established social, cultural, religious and traditional aspects in a completely new and different manner. They started re-questioning and redefining the already established norms and practices. In fact, all the above mentioned theories have not been accepted blindly. Every moment they critique each other about their existence and relevance. With the conclusion of the two massive world wars, several parts of the world from America to Africa and Asia, colonized by various European powers, were granted independence. The establishment of freedom in different nations all over the world changed the socio-cultural and political scenario altogether. The various political and aesthetic reorientations generated a new theoretical framework capable of explaining and interpreting the emergent cultural forms, known as 'Postcolonial Theory.' Though it was initially regarded as a celebratory concept, but with the passage of time it revealed the harsh complicacies that develop with the newly found independence.

\section{Post-Colonialism And Theatre}

Eminent thinker Partho Chatterjee in "The Nation and its Fragments: Colonial and Postcolonial Histories" throw a very significant question:

Does it serve any useful analytical purpose to make a distinction between the colonial state and the forms of the modern state? Or should we regard the colonial state as simply another specific form in which the modern state has generalized itself across the globe?

This question haunts every third world nations. A major problem faced by the newly independent nations was to erase any forms of colonial residue and re-establish their indigenous culture and traditions. In the process of doing it, individuals often falls victim to the colonial shadow against which they continuously struggle and this conflict continues to exist. V.S. Naipaul in one of his interviews rightly pointed out the cracks and fissures that develop when a nation is suddenly freed from the clutches of the colonizers. During the colonial era, the nation functions according to the whims and fancies of the colonizers. All forms of 
individualities are subjugated by the massive load of rules and regulations of the colonial regime. As a result, with the process of gaining independence when the shade of colonialism suddenly gets removed, then making self-decisions and developments appears to be an uphill task.

The development process often involves mimicking the colonizers or blindly adopting their traditions. Homi K. Bhabha feels that mimicry is an active form of resistance, a definite weapon to return the gaze of the colonial master as he is completely camouflaged. Thus, regarding colonial discourse Bhabha says: "The desire for a reformed, recognizable "Other", as a subject of a difference that is almost the same but not quite." (Nation and Narration, Page 34) These confusions not only remained limited in the field of society, culture or politics, but have also invaded the field of arts and literature, especially theatre. Taking a tour across the world, it is found that in different continents the postcolonial issues and grievances are complicated in their own manner and it has found its representation through the stage.

America attained its independence through the American Revolutionary War (1775-1783) that freed the American colonies from the control of Great Britain. But that never really ended the issues of class conflicts and racism. The American theatre also suffered from these politics. The newly formed government with its vague promises imposed illogical cultural laws upon the blacks and the other non-white races which limited their participation and expressions. With the passage of time, the scenario has surely changed but, these conflicts that erupted from the colonial times continue to haunt the present generation as well. The situation in Africa was no different, rather appeared to be much more complicated. The colonial situation of Africa has been altogether very different. The countries were invaded by multiple European powers and everybody had their own ruling policies. So, inspite of attaining independence the nations continues to suffer under the colonial shadows.

In Africa, community theatre plays a crucial role in creating indigenous awareness amongst the people. The community theatre is jointly funded by the respective national governments and organizations like UNICEF (United Nation International Children's Emergency Fund) or ACORD (Agency for Cooperation and Research in Development). As a result, in countries like, South Africa, Namibia, Angola, Zimbabwe and others the writers, actors and the producers are forced to work with a limited script. South Africa, who enjoys a decent economic position comparable to other African nations, still fights to eradicate the biggest challenge of racism from the face of its art and culture. The nations where the government is the sole source of financial support, faces an uphill task to develop scripts and acting according to their free will. In Namibia, once a theatre group's performance was banned abroad for spreading anti-national ideologies amongst the audience. Such instance exists in several other African nations as well. Thus the countries in Africa still face major problem to reestablish their indigenous art, culture and traditions as the respective governing bodies are still suffering from 'invisible' colonization. In Asia, especially in India, the scenario is somewhat different. The colonial shadow also haunts India but in a completely different manner.

The formal end of European colonialism in the middle of the twentieth century has created powerful instances of the linkage between political chronology and literary periodization across the globe. Like numerous former colonies, in India, the achievement of political autonomy and modern nationhood has signaled a symbolic break from the experience of colonial subjection and the beginning of a new revisionary phase in literary and cultural production. But the newly attained freedom developed a huge void in every aspect. Amongst all, the rich Indian traditional art and culture got distorted between the past and present. It got enmeshed in the cobweb of dilemma between "traditionalism" and "modernism." The postcolonial Indian theatre claims to function outside the Eurocentric theoretical and critical constructs, but in the process of developing new trends and ideas it often submits itself. The socio-cultural, traditional and linguistic plurality contributes largely to the inner conflicts and confusions in Indian theatre. Significantly, the historical origins of the evolving tradition of texts and performance practices lies in the genres, discourses and institutions of theatrical modernity that emerged under European influence in the colonial cities of Bombay and Calcutta during the second half of the nineteenth century.

\section{Modern Urban Indian Theatre}

Modern urban theatre in India is the result of the interpenetration of two major systems of theatrical representation: Indian and European, classical-traditional and modern, anti-realistic and realistic, provincial and metropolitan. It has borrowed its organizational structures, textual features and performance conventions from Europe (especially England), superseded traditional and popular indigenous performance genres, and found its core audience among the growing English-educated Indian middle class. The entrance of drama into print culture through original compositions and translations, various authorial and directorial practice, the bureaucratic meditations of the nation-state, the urban/rural split within audiences and the competition between various genres of performance or media of representation functions as major driving factors to make contemporary Indian theatre singular in relation to its own past and comparable to other forms of postcolonial practice. Despite the fact, that there is no dearth of Indian, American and Anglo-American criticism on the 
subject of Indian theatre, the ahistorical, fragmentary and neo-orientalist approaches have prevented any systematic recognition of postcolonial theatre as a historically significant subject.

\section{Development Of Marathi Theatre}

In order to focus on the postcolonial Marathi theatre it is important to permeate deep within and search for its roots. Theatre in Maharashtra has been prospering for 150 years and is bifurcated into two major trendsProfessional theatre and Parallel theatre. The Parallel or Other form of theatre, usually categorized as "folk", is alive for centuries as ritual or seasonal entertainments. The "Dashavatar" which is performed during the postharvest season between October and March in the Konkan region is basically on mythological stories about the ten avatars of Lord Vishnu. The "Tamasha", a raunchy, secular entertainment in the form of song, dance, satire and narrative, created for the amusement of the Peshwa armies in the eighteenth century, is still performed all over Maharashtra. Both these folk forms largely contributed towards the birth and evolution of the professional urban theatre. But in the contemporary times, Marathi theatre is pegged with several conflicts and controversies at different levels.

Vishnudas Bhave is regarded as the pioneer of Marathi theatre. In 1843, the colonial rule already firmly established, Raja of Sangli, Chintamanro Patwardhan greatly patronized arts and encouraged the talented individuals from every corner of human activity. The intervention of the British government in the Marathi regime played a crucial role in developing arts and culture in Maharashtra, especially theatre. After the English managed cleverly to separate the Gaekwad of Baroda, the Shinde of Gwalior and the Holkar of Indore from the Peshwa, the unified Marathi rule was weakened and fragmented. The regime of the last Peshwa and the last Shinde was extremely torturous and unbearable for the people. English East India Company, capitalizing on the scattered situation, wins the admiration of the common people through their dictum of 'proceeding towards gradual improvement.' (Playwright at the Centre, Chapter 1: Introduction, Page 3). The temporary peace and serenity that followed the establishment of British rule, allowed the people of Maharashtra and nearby regions to turn to cultural pursuits. But this peace was quite short-lived. It only shifted the position of the people from the chains of imperialism towards colonialism. This was gradually realized by the common masses and theatre began to play a pivotal role both in the form of entertainment and resistance among the people. G.P. Deshpande, in his two-part essay "Marathi Drama: The journey of a Social Consciousness" speculates:

The fact that drama is born within twenty-five years of the fall of the Peshwa regime...was most certainly a silent protest against imperialism; but more importantly, it was an attempt by the aristocratic class which had brought about its own political downfall, to seek its identity in a new field of activity, and closely reexamine its own face.

The peaceful environment allowed the folk theatre to travel from its home to nearby districts with their ritualistic entertainment. One of the greatest creations during this period was "Sita Swayamwar" by VishnudasBhave, which was a marvelous creation of "Sangeetnatak." His role in the development professional theatre in Maharashtra is unquestionable. With the passage of time, the culture of 'Bookish' or 'Prose' plays developed. It was largely influenced by the Shakespearean plays. The first "bookish" play Thorle Madhavrao Peshwa (The Elder Madhavrao Peshwa) was composed by Vinayak Janardan Kirtane (1840-1891) in 1857. During 1890s, the theatrical scenario in Maharashtra started undergoing major changes. The trend of Sangeetnatak and melodrama gradually shifted towards social and national issues of the colonial rule. Plays like "Manapaman" (Honour and Dishonour), "Keechakavadh" occupied the stage. These plays aroused in the people, a sentimental pride in their nation and culture. They were often allegorical in nature, contemporizing the ancient myth, culture and traditions. From the time of Bhargavram Vitthal Warerkar, Marathi stage became a powerful forum for intervening and representing contemporary social, economic and powerful situation.

The European theatrical trends continued to influence the Indians. The theatre, functioning as a weapon of resistance, deliberately restricted itself within the European ideological confines. During the nineteenth century, prolific playwright, Henrik Ibsen created a lot of influence on the Marathi playwrights. It obviously helped the playwrights to reject the age-old dilapidated Shakespearean structure and practiced a tighter structure of three acts with a well-defined exposition, climax and denouement. But the reasons behind the illogical adaptation of the Ibsen plays were unknown. If the adaptations are made within the newly-discovered sociocultural space, then Ibsen has absolutely no role to play. "Natyamanwantar" was formed at the eve of Indian independence with the specific purpose of bringing modern drama to the Marathi stage. The usage of songs, the structure of the play, the stage design and the acting style all contributed towards its development. In Europe, naturalism reigned but it was not possible to introduce this parallel trend in India. So, undoubtedly Ibsen and his contemporaries influenced pre-independent modern drama. After India's independence in 1947, Marathi drama started experimenting with several theatre forms. The mainstream stage nostalgically continued to hark the old traditions of "Sangeetnatak", tearful family melodramas and the "experimental" or "parallel" theatre shifted the trend of blank adaptation towards original creations. This was the beginning of the internal conflicts in the Marathi theatre which branched into several directions later on. The new, amateur playwrights found it 
significant to represent the socio-cultural and political reality of post-independent India. B.V. Warerkar, in his autobiographical account "Mazha Nataki Sansar" says:

The fact of our liberation from slavery finds no mention in the novels and plays written today...In

Maharashtra alone, eighty to ninety plays had been confiscated by the government for daring to incorporate scenes which could be viewed as a direct or indirect propagation of anti-government sentiment...I am not suggesting that plays should describe today's reality as it is. They would not be plays if they did so. They would be reportage. What I am suggesting is that today's reality should find its reflection in the dialogues, events or dramatic devices used. They should have a connection, as theatre, with the outside world.

The changing wind of the modern Marathi theatre highlighted the different faces of reality. The established social, cultural, political and historical institutes were questioned. The mainstream stage was also affected by these changes. They broke out from the cocoon of family melodrama and started exploring the various fields of individual existence. S.N. Pendse's plays were located in the Konkan, where the language, beliefs and lifestyles were quite different from those the theatregoer was accustomed to seeing. Jayant Dalvi wrote on various aspects of human existence, which had hitherto not been staged, such as the problems of old people in a new society, the inner lives of the mentally disturbed, middle-class sexuality and the decline of values in society and politics. The plays of Vijay Tendulkar invited a lot of controversies especially "Ghasiram Kotwal" (1972). He de-historicized the age old myth of the heroic deeds of Nana Phadnavis and revealed the grey side of his character. The 'astute statesman' image of Nana was totally deconstructed, painting him as a lustful, power-mongering figure. Initially the audiences appreciated the theatrical power of the play, but soon it found the rage of Pune's self-appointed cultural watchdogs who voiced for banning the play.

Ratnakar Matkari is regarded as one of the most prolific playwrights on the Marathi stage. His creations expand over varied forms. Since Pendse the attitude of the playwrights changed a lot. Instead of blankly copying the Western standards, new forms were also experimented on the stage. It reached a new height with Matkari, who through his work "Lokkatha" introduced a completely new version of dialogue formation. The script of "Lokkatha" evolved with dialogues based on actors' improvisations. This play marked a unique development in Marathi theatre in the manner of its presentation and reception. It was the first docu-drama to be performed on Marathi stage dealing with the problems of the rural underprivileged thus creating an enduring difference to the urban audience. Theatre in Maharashtra continued to proceed towards "realism" through Achyut Vaze's"Chal Re Bhoplya Tunuk Tunuk" (Giddyup, Pumpkin, Giddyup). This play very aptly framed the regular, idiosyncratic speech patterns and the uni-dimensional real life caricature-characters.

Political playwriting in Marathi theatre began with Govind Purushottam Deshpande whose play AdharYatra, was again an attempt to redefine and transform the history of Vasundhara into the myth of Anushuya, with the politics of class and gender at the background. Vasundhara, a "sex object" of Daulatrao, gradually transcends into the eternal form of woman. She is as much the past as she is the present. In Indian tradition the woman is one who suffers and thereby grows in moral stature. The unattended and un-discussed postcolonial social issues of India are highlighted in the plays of Satish Alekar. Mahanirvan speaks about the politics and the traditional vanities associated with the death of an individual and Begum Barve reveals the multi-layered oppression of both the male and the female in Theatre of Impersonality. Mahesh Elkunchwar's plays like Wada Chirebandi (The Old-stone Mansion, 1985), Party, God Son, Sonata or Holi penetrate deep into the psychology of the different characters belonging to different strata of the society, extracting the existential angst that occupies their mental core.

During this time, the Brechtian theatrical techniques played a highly influential role amongst the playwrights. The participation and interaction of the audience with the stage was a result of the influence of Bertolt Brecht. His systematic separation of "epic theatre" from the older "dramatic theatre" offers the most comprehensive internally consistent twentieth century program for political representation, predicated on a materialist rather than idealist understanding of history, antirealist staging, non-linear narrative progression, and an appeal to reason and action rather than emotional catharsis in the spectator. But unlike Ibsen, Brecht's plays were never blindly copied by the modern playwrights. They were often adopted for the Indian stage, keeping the contemporary Indian scenario at the center.

In the contemporary times Marathi theatre exists in a very complicated state. The earlier Parallel theatre playwrights have experimented with such wide range of concepts and ideas that hardly anything new is left for exploration. Whenever, the contemporary playwrights attempt to create and produce something unique, immediately a parallelism is drawn with their predecessors. Yet playwrights like Premanand Gajvi, Rajeev Naik, Sushma Deshpande or Shafaat Khan struggles to find their own unique themes, techniques and forms of expressions, addressing issues which belong exclusively to the contemporary times. Though the playwrights of today often refer to the influence of the predecessors behind their development, yet they reject any definite and established forms of writing that was earlier practiced. 


\section{Conclusion}

In the conclusion, it is worth re-emphasizing that Marathi 'postcolonial theatre' has been principally divided into two parts: "urban" literary drama and experimental performance, associated with dramatic authorship, publication and translation at one level, and with institutionalized amateur, professional and statesupported productions at another. The different thoughts, views and the forms of theatre lead to various forms of ideological conflicts. These conflicts and confusions were created with the vision of eradicating the dark colours of colonialism from the canvas of postcolonial Marathi theatre.

\section{References}

[1] Shanta Gokhale. Playwright at the Centre: Marathi Drama from 1843 to the Present. (Calcutta: Seagull Books, 2000)

[2] Pramod K. Nayar. Literary Theory Today. (New Delhi: Asia Book Club, 2006)

[3] David Kerr. African Theatre: Southern Africa. (New Jersey: Africa World Press, 2004)

[4] Aparna Bhargava Dhadwadker. Theatres of Independence: Drama, Theory and Urban Performance in India since 1947. City: University of Iowa Press, 2005)

[5] Partha Chatterjee. The Nation and its Fragments: Colonial and Postcolonial Histories. (New Jersey: Princeton University 1993)

[6] Mahesh Elkunchwar. Collected Plays of Mahesh Elkunchwar, (New Delhi: Oxford University Press, 2009)

[7] Bhargavram Vitthal Warerkar.Mazha Nataki Sansar,(Mumbai: Popular Pakashan, 1995)

[8] G.P. Deshpande. Marathi Drama: The Journey of a Social Consciousness. (Mumbai: Popular Prakashan, 1991) 